\title{
PENGEMBANGAN MULTIMEDIA PEMBELAJARAN PADA MATERI SISTEM INDERA DENGEN EVALUASI PERMAINAN BOKAH
}

\section{LEARNING MULTIMEDIA DEVELOPMENT IN SENSORY SYSTEM MATERIAL WITH BOKAH GAME EVALUATION}

\author{
Primadya Anantyarta ${ }^{1)}$, Rida Juniarti ${ }^{2}$ \\ 1), 2) IKIP Budi Utomo Malang, Jalan Citandui No. 46, Malang, 65111 \\ anantyarta@gmail.com
}

diterima: 13 Januari 2020; dipublikasi: 31 Oktober 2020

DOI: $10.32528 /$ bioma.v5i2.4009

\begin{abstract}
ABSTRAK
Autoplay adalah perangkat lunak yang dapat digunakan dalam membuat perangkat lunak dengan menggabungkan berbagai tipe media misalnya gambar, suara, video, teks, dan flash ke dalam slide presentasi yang ingin dibuat. Asal usul permainan yang dikenal dengan nama "Bokah" merupakan permainan salah satu suku Melayu di Kabupaten Sanggau Kalimantan Barat dan diambil dari bahasa Melayu daerah tersebut. Media BOBERDIAPLAY ini mampu mempermudah pendidik dalam penyampaian materi dan peserta didik dalam memahami materi, serta dilakukan evaluasi menggunakan permaianan Bokah. Model pengembangan ADDIE Terdapat 5 tahap tetapi dalam penelitian ini hanya dilakukan sampai tahap development (pengembangan). Pengembangan BOBERDIAPLAY (Bokah Berbasis Autoplay ) pada materi sistem indera layak untuk digunakan dalam pembelajaran karena mendapat hasil presentase dari ahli media 94,4\% dan presentase ahli materi 97\%. Penelitian ini tergolong sangat valid dan layak digunakan dengan sedikit revisi.
\end{abstract}

Kata Kunci: Pengembangan, Media Autoplay, Bokah.

\begin{abstract}
Autoplay is software that can be used in creating software by combining various types of media such as images, sound, video, text, and flash into the presentation slide you want to create. The origin of the game known as "Bokah" is a game of one of the Malay tribes in Sanggau Regency, West Kalimantan and is taken from the local Malay language. The BOBERDIAPLAY media is able to make it easier for educators in delivering material and students in understanding the material, and evaluations are carried out using the Bokah game. The ADDIE development model There are 5 stages but in this research it is only carried out until the development stage. The development of BOBERDIAPLAY (Autoplay Based Bokah) on the sensory system material is suitable for use in learning because it gets a percentage of $94.4 \%$ from media experts and $97 \%$ of material experts. This research is classified as very valid and worthy of use with a few revisions.
\end{abstract}

Keywords: Development, Autoplay Media, Bokah. 


\section{PENDAHULUAN}

Media pembelajaran adalah suatu alternatif yang dapat membantu dalam suatu proses belajar mengajar. Seorang pendidik diharuskan untuk menggunakan media pembelajaran yang dapat membuat peserta didik lebih aktif agar dapat membantu kegiatan belajar mengajar (Emda, 2011). Dalam proses pembelajaran terdapat metode dan media, metode mengajar adalah salah satu cara yang digunakan oleh pendidik dalam melakukan interaksi dengan peserta didik agar informasi dapat sampai kepada peserta didik dan tercapainya tujuan pembelajaran yang diharapkan. Sedangkan media pembelajaran sebagai alat bantu dalam mengajar yang berfungsi untuk memperjelas materi yang disampaikan oleh pendidik pada pelaksaan proses pembelajaran (Triayanto, Anitah, \& Suryani, 2013). Autoplay adalah perangkat lunak yang dapat digunakan dalam membuat perangkat lunak dengan menggabungkan berbagai tipe media misalnya gambar, suara, video, teks, dan flash ke dalam slide presentasi yang dibuat (Anantyarta, Listya, \& Sari, 2017). Pembelajaran sains berbasis permainan tradisional ini dilakukan dengan cara penggambaran/penyusunan sains asli yang terdapat dalam suatu tradisi untuk meningkatkan kesejahteraan masyarakat (Khusniati, 2014). Asal usul permainan yang dikenal dengan nama "Bokah" merupakan permainan salah satu suku Melayu di Kabupaten Sanggau Kalimantan Barat dan diambil dari bahasa Melayu daerah tersebut. Kata lain dari Bokah berarti "menyepak" tempurung dengan mengunakan kedua kaki kanan dan kiri hingga tempurung tersebut terbuka . Dari rumusan masalah di atas bertujuan agar generasi sekarang tidak melupakan kearifan lokal yang ada karena kemajuan teknologi semakin pesat di era abad 21. Penulisan ini bermanfaat untuk generasi sekarang maupun peserta didik, pendidik, masyarakat, dan penulis agar tetap mengingat dan melestarikan kearifan lokal yang ada di Indonesia.

\section{METODE}

\section{Metode Penelitian}

Metode penelitian ini merupakan salah satu metode yang dapat digunakan untuk menghasilkan suatu produk dengan melalui beberapa tahap pengujian sehingga menghasilkan produk yang siap digunakan (Sugiono, 2013 dalam Restini, 2018). 


\section{Tempat dan Waktu}

Tempat observasi di IKIP Budi Utomo Malang, waktu penelitian dimulai pada tanggal 25 s/d 28 Oktober 2019. Lama pembuatan media kurang lebih selama 4 hari dan lama pembuatan karya tulis kurang lebih selama 7 hari.

\section{Alat dan Bahan}

Penelitian ini menggunakan alat dan bahan yaitu komputer/laptop dan rubrik pertanyaan.

\section{Analisis data}

Pada tahap uji coba, data yang didapat menggunakan angket pendahuluan dan angket penilaian validasi guna untuk meminta kritik, saran masukan dan perbaikan agar mendapatkan hasil analisis yang di inginkan dari hasil produk pengembangan yang berupa BOBERDIAPLAY (Bokah Berbasis Media Autoplay) pada materi sistem indera.

Data yang didapat kemudian dikelompokan menjadi dua yaitu data kuantitatif dan data kualitatif. Data kualitatif merupakan data yang berbentuk symbol, sedangkan data kuantitatif merupakan data yang di dapat dari angket yang berupa angka dan dan data ini akan dikualitatifkan dengan melalui perhitungan dalam pertanyaan angket untuk menentukan presentase dengan rumus sebagai berikut:

$$
\mathrm{P}=\frac{\sum \mathrm{x}}{\sum \mathrm{xi}} \mathrm{x} 100 \%
$$

Keterangan :

$\mathrm{P}$ : persentase kelayaka

$\sum \mathrm{x}$ : Jumlah total skor jawaban validator

$\sum x i$ : Jumlah tptal skor jawaban tertinggi

100\% : Konstanta (Arikunto, 2007 dalam Restini, 2018). 
Berdasarkan perhitungan tersebut diperoleh kriteria kelayakan sebagai berikut:

Tabel 1. Kualifikasi Tingkat Kelayakan Berdasarkan Persentase

\begin{tabular}{ccc}
\hline Prosentase $(\%)$ & Tingkat Kevalidan & Keterangan \\
\hline $85-100$ & Sangat valid & Tidak Revisi \\
\hline $69-84$ & Valid & Tidak Revisi \\
\hline $53-68$ & Cukup valid & Sebagian Revisi \\
\hline $37-52$ & Kurang valid & Revisi \\
\hline $20-36$ & Sangat kurang valid & Revisi \\
\hline
\end{tabular}

(Sumber : Widya, 2015 dalam Restini, 2018)

Berdasarkan keterangan di atas, media pembelajaran BOBERDIAPLAY dinyatakan valid dengan memenuhi kriteria skor 69-84 yang terdapat pada angket penilaian dari validasi ahli media maupun validasi ahli materi. Penelitian media pembelajaran ini mendapatkan kriteria valid.

\section{HASIL DAN PEMBAHASAN}

\section{1) Data Validasi Ahli Materi}

Validator ahli materi dalam penelitian pengembangan ini adalah salah satu ahli materi dari program studi pendidikan biologi IKIP Budi Utomo Malang yang memiliki keahlian dalam bidang Sistem Indera. Validasi dilakukan dengan cara menampilkan media pembelajaran disertai lampiran yang telah dibuat berupa angket, dalam proses validasi ini peneliti dan ahli materi membincangkan mengenai kualias materi agar lebih luas dan mudah dipahami. Evaluasi dari ahli materi ditulis semua didalam angket yang telah disediakan untuk meningkatkan keluasan dalam materi pembalajaran. Angket penilaian berisi aspek kualitas materi pembelajaran yang meliputi aspek pembelajaran dan aspek kebenaran isi. Hasil evaluasi berupa nilai untuk aspek kualitas materi pembelajaran dan isi menggunakan skala 1 sampai 4, sedangkan aspek kebenaran materi pembelajaran dan isi berupa komentar dan saran perbaikan. Jumlah penilaian yang dihasilkan dari validator ahli materi dalam aspek pembelajaran dan aspek kebenaran isi mendapatkan persentase kelayakan sebesar 97\% dengan mendapat skor dari validator 66 dari skor maksimal 68 dari skala 4. Perolehan ini menunjukan materi pada pembelajaran ini termasuk dalam 
kategori sangat baik dengan kriteria sangat valid atau dapat digunakan dengan sedikit revisi.

\section{2) Data Validasi Ahli Media}

Validator ahli media dalam penelitian pengembangan ini adalah salah satu ahli media dari Program Studi Pendidikan Biologi IKIP Budi Utomo Malang yang memiliki keahlian di bidang teknologi. Validasi ini dengan cara memberikan media pembelajaran kepada validator disertai dengan angket yang berisi aspek tampilan dan aspek pemrograman. Validasi ahli media dilakukan untuk menilai dua aspek yaitu aspek tampilan dan aspek pemrograman. Jumlah penilaian yang dihasilkan dari validator ahli media dalam aspek tampilan dan aspek pemrograman mendapatkan persentase kelayakan sebesar 94,4\% dengan mendapat skor dari validator 68 dari skor maksimal 72 dari skala 4. Perolehan ini menunjukan materi pada pembelajaran ini termasuk dalam kategori sangat baik dengan kriteria sangat valid atau dapat digunakan dengan sedikit revisi.

\section{KESIMPULAN DAN SARAN}

Pengembangan BOBERDIAPLAY (Bokah Berbasis Autoplay) pada materi sistem indera layak untuk digunakan dalam pembelajaran karena mendapat hasil persentase dari ahli media sebesar 94,4\% dan persentase ahli materi sebesar 97\%. Media BOBERDIAPLAY ini tergolong sangat valid dan layak digunakan dengan sedikit revisi.

Media pembelajaran dikembangkan sangat menarik dan dapat digunakan sebagai alternatif sumber belajar siswa, namun perlu perbaiki pada keterangan gambar agar lebih jelas. Untuk materi yang diterapkan dalam multimedia Autoplay sangat baik dan layak digunakan dengan sedikit revisi.

\section{DAFTAR PUSTAKA}

Anantyarta, P., Listya, R., \& Sari, I. (2017). Pengembangan Media Auto Play Dengan Metode Means Ends Analysis ( MEA) Pada Matakuliah Genetika. Pros.Seminar Pend.IPA Pascasarjana UM, 2, 532-538.

Emda, A. (2011). Pemanfaatan Media Dalam Pembelajaran Biologi Di Sekolah. Jurnal 
Ilmiah Didaktika, 12(1), 149. Https://Doi.Org/10.22373/Jid.V12i1.444

Falahudin, I. (2014). Pemanfaatan Media Dalam Pembelajaran. Lingkar Widyawiswara, 1(Desember), 104-117.

Khusniati, M. (2014). Model Pembelajaran Sains Berbasis Kearifan. Jurusan Ipa, Fmipa Universitas Negeri Semarang, 3(1), 67-74.

Purwanto, \& Rahmatina, Rusumu Siami. (2019). Aplikasi Pembelajaran Biologi Berbasis Android “Fun - B ” Kelas Vii Smp. 8(1), 1-5.

Rahayu, A., \& Andini, D. W. (2019). Media Pembelajaran Ramah Lingkungan Bagi Guru. (April), 65-70.

Rahmawati, W. (2015). Pengembangan Media Pembelajaran Melalui Multimedia Autoplay Untuk Peningkatkan Hasil Belajar Siswa Pada Mata Pelajaran Sejarah Kebudayaan Islam Di Kelas X Man Malang Ii Kota Batu.

Ridwan, M. (2016). Pendidikan Karakter Berbasis Permainan Tradisional Siswa Sekolah Dasar Di Sumenep Madura. Fkip Universitas Ahmad Dahlan.

Subekti, H., Taufiq, M., Susilo, H., Ibrohim, \& Suwono, H. (2018). Mengembangkan Literasi Informasi Melalui Belajar Berbasis Kehidupan Terintegrasi Stem Untuk Menyiapkan Calon Guru Sains Dalam Menghadapi Era Revolusi. Education And Human Development, 3(2), 81-90.

Triayanto, E., Anitah, S., \& Suryani, N. (2013). Peran Kepemimpinan Kepala Sekolah Dalam Pemanfaatan Media Pembelajaaran Sebagai Upaya Peningkatan Kualitas Proses Pe,Belajaran. 1(2), 226-238. 7/Lomba Media/187-346-1-SM.

Wijaya, I., \& Rakhmawati, L. (2015). Pengembangan Media Pembelajaran Autoplay Media Studio Pada Mata Pelajaran Perekayasaan Sistem Audio Di SMK Negeri 3 Surabaya. Jurnal Pendidikan Teknik Elektro, 4(3), 957-963. 